\title{
Alternative financing for health care: A path to sustainability?
}

\author{
R. Sacha Bhatia MD MBA
}

$\mathrm{T}$ he year 2011 may be remembered as one of the most important to the future of medicare in Canada. A Conservative majority government was elected in May to preside over the next major round of negotiations for federal-provincial transfer payments for health care, with the current deal set to end in 2014. The conditions of the upcoming negotiations will be much different from those of the negotiations in 2004, with the federal government and most of its provincial partners struggling to eliminate deficits accrued during one of the worst fiscal crises of the last 100 years.

It is against this backdrop of deficits and fiscal uncertainty that many influential policy leaders are questioning the sustainability of our publicly funded system of health care. In a report from the C.D. Howe Institute (a respected economic think tank), former Bank of Canada governor David Dodge, with coauthor Richard Dion, suggested severe cuts to health care, increased taxes or increased personal payments (such as copayments) to manage the rising costs of public health care. ${ }^{1}$ The Fraser Institute, a libertarian economic and public-policy think tank, has taken Canada's deficit position as an opportunity to boldly declare that the federal government should suspend the Canada Health Act, let individuals buy private insurance, allow health providers to charge fees in addition to what medicare covers and allow for copayments for publicly funded medical goods and services. ${ }^{2}$ These sentiments have been echoed by many other free-market advocates, who suggest that free-market solutions are the only way to save our cherished, publicly funded system of health care. Putting aside the questions of whether these proposed systems are fair, equitable or compatible with Canadian values, would such reforms actually create a sustainable, affordable health care system?

The answer, looking at the evidence, is no. The Fraser Institute's report, echoed by the C.D. Howe Institute, frets that health spending will be more than $50 \%$ of the provincial budget of most provinces by 2017. Although this is concerning, one must remember that this metric for measuring spending on health care is also reflective of the taxes collected and spending on other programs unrelated to health. Whereas overall tax revenue has gone up, the tax rate across the country has actually been cut quite dramatically from reductions in personal income taxes, the Goods and Services Tax (GST) and corporate tax rates. ${ }^{3}$ In short, use of the measure of health spending as a percent of the provincial budget can be a misleading measure of fiscal impact.

On the other hand, when we look at a standard measure of costs for health care used by the Organisation for Economic Co-operation and Development (OECD), spending on health care as a percent of gross domestic product (GDP), Canada spends about $10.4 \%$ of GDP on health care. This is similar to the spending of many European countries, such as Germany (10.5\%), France (11.2\%), Switzerland (10.7\%), Belgium (11.1\%), Sweden (9.4\%) and the Netherlands (9.9\%), and substantially less than the spending of the United States, which spends $16.0 \%$ of its GDP on health care. ${ }^{4}$ Each of these countries finances health care differently. In Switzerland, citizens are required by law to purchase private health insurance. In Sweden, health care is funded mainly through taxes levied at the municipal and county level. The US has a complex system of government funding (Medicare for those older than 65 years, Medicaid for those with low incomes and a publicly delivered health care system for military veterans), an employer-based insurance system and a pay-as-you-go system. Despite the variety of ways to finance health care, the rate of spending for health care has outstripped economic growth in almost every country in the OECD for the past 15 years, and containment of the growth of health care as the population ages is a major concern for all developed economies, not just Canada.

But would some of the specific options regarding user fees and private insurance proposed by the Fraser Institute and others save money for our system of public health care? Would allowing some well-off Canadians to remove themselves from the public insurance scheme create substan-

\section{KEY POINTS}

- Budgetary deficits at federal and provincial levels have raised questions about the sustainability of Canada's publicly funded system of health insurance.

- Alternative financing for health care, including private insurance, would likely not reduce the costs of health care because of the high concentration of costs in a small portion of the population.

- User fees have not been effective in reducing overall costs of health care and are associated with higher rates of admissions to hospital. 
tial savings to improve medicare for the rest of us? Would user fees decrease costs by removing unnecessary visits by the worried well?

The evidence, again, points to no. A TD Economics report on health care published in 2010 cautions us that private financing does not lead to large public savings. ${ }^{5}$ Multiple-payer systems are more expensive to administer. The OECD conservatively estimated that the US spends $8 \%$ of its budget for health care on administration, compared with $2 \%$ spent in Canada. ${ }^{4}$ Woolhandler and colleagues found that the discrepancy of administrative costs between Canada and the US is even higher than that suggested by the OECD. The authors showed the administrative costs in the US to be more than threefold higher, at $\$ 1059$ per capita, compared with $\$ 307$ per capita in Canada. ${ }^{6}$ Put another way, application of the estimates of US administrative costs to the Canadian system would increase costs by $\$ 23$ billion per year.

But there is an even more compelling reason that private financing does not save the public system money. It can be found in a landmark report published by the Ontario Hospital Association, the Ontario Association of Community Care Access Centres and the Ontario Federation of Community Mental Health and Addiction Programs in 2010. These organizations analyzed use of health care in Ontario and found that 5\% of the Ontario population accounts for $84 \%$ of all spending on health care. ${ }^{7}$ This portion of the population often comprises patients with chronic diseases and people from vulnerable populations, such as the frail elderly and the economically disadvantaged. ${ }^{7}$ None of these Canadians would likely be able to afford private insurance; thus, the bulk of health care costs would continue to rest with the public system.

And what of user fees? A recent study published in the New England Journal of Medicine included US patients with increasing copayment plans versus those with stable or no copayment plans. The researchers found that the group with increasing copayments went to the doctor less often but ended up with more admissions to hospital at a higher cost to the system. ${ }^{8,9}$ Although one must be careful to draw conclusions about the economic impact, one can speculate that a reduction in low-cost ambulatory visits would be unlikely to offset the high costs of visits to emergency departments and admissions to hospital.

The bottom line is that our health system, like health systems around the world, needs to continue to invest and modernize its delivery systems to improve the health of our citizens, which, in turn, will make health care sustainable. A national strategy for pharmacare and a strategy for bulk purchasing of medical equipment could save the government, both federal and provincial, billions of dollars. Improving the health of our country's most vulnerable citizens (which, incidentally, includes Aboriginal Canadians, who have their health care delivered to them very poorly by the federal government) would actually go the furthest in lowering the cost of health care over time. A comprehensive strategy for health promotion to begin to curb the rising rate of obesity and diabetes in our population would also go a long way toward ensuring our system is sustainable for future generations. Creating home care services that keep the frail elderly and chronically ill in their homes and not in institutions will be fundamental in reducing the demand on our hospitals and long-term care homes. Ensuring any new money given to the provinces for health care is tied to accountability measures that include improving outcomes and showing value would also help.

Alternative systems of financing may have benefits to certain individuals and groups within society. However, suggestions that these financing models will somehow make our health care system financially sustainable are not supported by evidence. If anything, Canadians cannot afford to go down that road.

\section{References}

1. Dodge DA, Dion R. Chronic healthcare spending disease: background and methodology [working paper]. Toronto (ON): C.D Howe Institute; 2011. Available: www.cdhowe.org/pdf/Working Paper_327.pdf (accessed 2011 Aug. 11).

2. Skinner B, Rovere M. Canada's medicare bubble: Is government health spending sustainable without user-based funding? Calgary (AB): Fraser Institute; 2011.

3. Chen D, Mintz J. Canada's 2010 tax competitiveness ranking: moving to the average but biased against services. Calgary $(\mathrm{AB})$ : University of Calgary, School of Public Policy, SPP Research Papers; 2011. p. 1-16. Available: http://policyschool.ucalgary.ca /files/publicpolicy/2010tax\%20comp\%20rank\%20online.pdf (accessed 2011 Aug. 11).

4. OECD health data 2011. Paris (FR): Organisation for Economic Co-operation and Development (OECD); 2010. Available: www .oecd.org/health/healthdata (accessed 2011 Aug. 11).

5. Drummond D, Burleton D. Charting a path to sustainable health care in Ontario: 10 proposals to restrain cost growth without compromising quality of care. TD Economics Special Reports. Toronto (ON): TD Bank Financial Group; 2010. Available: www.td.com/economics/special/db0510_health_care.pdf (accessed 2011 Aug. 11)

6. Woolhandler S, Campbell T, Himmelstein DU. Costs of health care administration in the United States and Canada. $N$ Engl J Med 2003;349:768-75.

7. Ideas and opportunities for bending the health care cost curve: advice for the Government of Ontario. Scarborough (ON): Ontario Association of Community Care Access Centres; Ottawa (ON): Ontario Federation of Community Mental Health and Addiction Programs; Toronto (ON): Ontario Hospital Association; 2010. Available: www.oha.com/KnowledgeCentre/Library/Documents /Bending\%20the\%20Health\%20Care\%20Cost\%20Curve\%20(Final $\% 20$ Report\%20-\%20Apri1\%2013\%202010).pdf (accessed 2011 Aug. 11).

8. Trivedi AN, Rakowski W, Ayanian JZ. Effect of cost sharing on screening mammography in Medicare health plans. $N$ Engl $J$ Med 2008;358:375-83.

9. Trivedi AN, Moloo H, Mor V. Increased ambulatory care copayments and hospitalizations among the elderly. N Engl J Med 2010;362:320-8

Affiliations: Dr. R. Sacha Bhatia is a clinical and research fellow at the Division of Cardiology, Massachusetts General Hospital, Boston, Mass., and a research fellow at Harvard Medical School, Boston, Mass. 